\title{
WHAT'S \\ HAPPENING \\ IN \\ Without Borders
}

\section{From the Editor}

Gretchen Birbeck, MD, MPH

\section{Global Stuff You Should Know}

We are aware of the increasing shortage of neurologists practicing in the United States, ${ }^{1}$ but in some low- and middle-income countries (LMIC), such as Cambodia, the number of practicing specialists may be in the single digits. In a recent Global stuff you should know titled "Bringing neuroscience to Cambodia," Dr. Soma Sahai-Srivastava outlined the need for her summer teaching program and follows with information on the program that will begin its 5th year in July 2018. "In my many trips to Cambodia in the last decade, volunteering solo, I realized that there are no short-term volunteering opportunities for neurology clinical care, unlike other specialties like emergency medicine, pediatrics, surgery, etc. No neurology outpatient clinics or inpatient specialized programs existed until recently. There were only 3 neurologists in the country in 2012. ${ }^{2}$ The first internal medicine residency program launched in 2011 and there are still no adult or pediatric neurology residency programs. There is one pediatric neurosurgeon and no pediatric neurologists in the entire country. There is a lack of commonly prescribed neurologic medications (e.g., phenytoin and phenobarbital are the only antiepileptics available at the public hospitals). Under these circumstances, I realized that rather than volunteering in clinics treating individual patients, the first priority was neuroscience education and curriculum development at all levels: undergraduate, medical school, and postgraduate."

\section{References}

1. Dall TM, Storm MV, Chakrabarti R, et al. Supply and demand analysis of the current and future US neurology workforce. Neurology 2013;81:470-478.

2. Loo KW, Gan SH. Burden of stroke in Cambodia. Int J Stroke 2013;8:475-478.

\section{Blog}

Read the Without Borders blog for timely posts by the editor and invited guests. NPub.org/wbblog 


\section{Neurology}

\section{What's happening in Without Borders \\ Neurology 2018;91;174 \\ DOI 10.1212/WNL.0000000000005883}

This information is current as of July 23, 2018

Updated Information \& Services

References

Permissions \& Licensing

Reprints including high resolution figures, can be found at: http://n.neurology.org/content/91/4/174.full

This article cites 2 articles, 1 of which you can access for free at: http://n.neurology.org/content/91/4/174.full\#ref-list-1

Information about reproducing this article in parts (figures,tables) or in its entirety can be found online at:

http://www.neurology.org/about/about_the_journal\#permissions

Information about ordering reprints can be found online:

http://n.neurology.org/subscribers/advertise

Neurology ${ }^{\circledR}$ is the official journal of the American Academy of Neurology. Published continuously since 1951, it is now a weekly with 48 issues per year. Copyright (O 2018 American Academy of Neurology. All rights reserved. Print ISSN: 0028-3878. Online ISSN: 1526-632X.

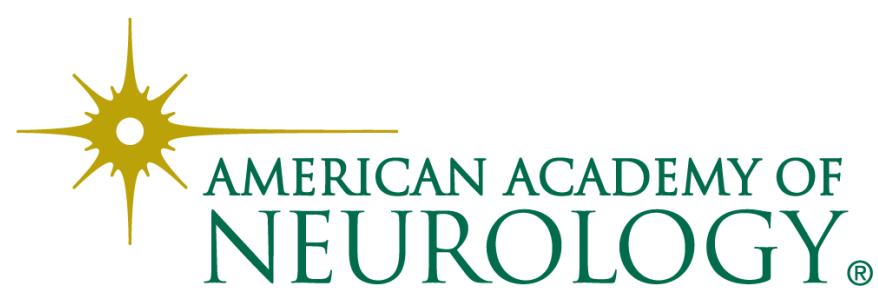

